\title{
Pertumbuhan Selada Merah (Lactuca sativa L. var. Red Rapid) dan Selada Hijau (Lactuca sativa L. Grand Rapids) dengan Sistem Hidroponik Apung dengan Pemberian Dosis Pupuk Organik Cair (POC) Bioslurry dan AB Mix yang Berbeda
}

\section{Growth of Red Lettuce (Lactuca sativa L. var. Red Rapid) and Green Lettuce (Lactuca sativa $\mathbf{L}$. Grand Rapids ) Plant on Floating Hydroponic System with Different Dosage of Bioslurry Liquid Organic Fertilizer and AB Mix}

\author{
Muhamad Nazif Anwary ${ }^{1 *}$, W.Slamet ${ }^{2}$, Florentina Kusmiyati ${ }^{2}$ \\ ${ }^{1}$ Program Studi Agroteknologi, Departemen Pertanian, Fakultas Peternakan dan Pertanian \\ Universitas Diponegoro \\ ${ }^{2}$ Departemen Pertanian, Fakultas Peternakan dan Pertanian, Universitas Diponegoro \\ *Email : nazifanwary@gmail.com
}

Diterima 25 Maret 2019 / Disetujui 6 Agustus 2019

\begin{abstract}
ABSTRAK
Tanaman selada (Lactuca sativa L.) merupakan tanaman sayuran daun yang dapat dibudidayakan dengan sistem hidroponik untuk memenuhi kebutuhan sayur pada tingkat rumah tangga. Pemberian jenis dan dosis larutan nutrisi yang tepat akan menghasilkan pertumbuhan dan hasil produksi tanaman yang baik. Penelitian ini bertujuan untuk mengkaji pengaruh pemberian pupuk organik cair (POC) bioslurry dan larutan nutrisi komersil $\mathrm{AB}$ mix dengan dosis yang berbeda terhadap pertumbuhan tanaman selada merah (var. Red Rapid) dan selada hijau (var. Grand Rapids) yang dibudidayakan dengan sistem hidroponik apung. Parameter penelitian adalah tinggi tanaman, jumlah daun, kadar klorofil total, kadar aktivitas nitrat reduktase (ANR), dan bobot segar tajuk tanaman. Hasil penelitian menunjukkan bahwa pemberian dosis larutan nutrisi $52,5 \mathrm{~mL} \mathrm{AB}$ mix $+17,5 \mathrm{~mL}$ bioslurry menghasilkan rata-rata pertumbuhan dan hasil produksi tanaman yang tertinggi pada kedua kultivar tanaman selada, diikuti oleh pemberian dosis larutan nutrisi $35 \mathrm{~mL} \mathrm{AB}$ mix $+17,5 \mathrm{~mL}$ bioslurry. Pemberian dosis larutan nutrisi $70 \mathrm{~mL}$ bioslurry menghasilkan rata-rata pertumbuhan dan produksi tanaman terendah pada kedua kultivar tanaman selada.
\end{abstract}

Kata Kunci: AB mix, bioslurry,. hidroponik, nutrisi, selada

\section{ABSTRACT}

Lettuce (Lactuca sativa L.) is one of the green leafy vegetables that can be grown on the hydroponic system to fulfill household needs of vegetables. Providing the right nutrient solution type and dosage will increase plant growth and crop production. This study aimed to analyze the effects of using bioslurry liquid organic fertilizer and $\mathrm{AB}$ mix commercial nutrient solution on growth and production of red lettuce (var. Red Rapid) and green lettuce (var. Grand Rapids). Results indicated that using a dose of $52,5 \mathrm{~mL} \mathrm{AB}$ mix $+17,5 \mathrm{~mL}$ bioslurry nutrient solution showed the highest growth and crop production rate in both lettuce cultivars, followed by 35 $\mathrm{mL} \mathrm{AB} \mathrm{mix}+35 \mathrm{~mL}$ bioslurry nutrient solution. Application of dose of $70 \mathrm{~mL}$ bioslurry nutrient solution showed the lowest rate of plant growth and crop yield on both cultivars.

Keywords: AB mix, bioslurry, hydroponic, lettuce, nutrient

\section{PENDAHULUAN}

Tanaman selada (Lactuca sativa L.) merupakan tanaman sayuran daun yang dikonsumsi masyarakat Indonesia karena bergizi. Tanaman selada memiliki ciri-ciri daun berwarna hijau yang berbentuk lebar dan tipis. Tepi daun selada bertipe keriting sehingga menyebabkan tanaman selada tampak keriting (Supriyadi et al., 2017). Tanaman selada dapat dibudidayakan pada lingkungan rumah tangga untuk memenuhi kebutuhan rumah tangga akan sayuran. Budidaya 
tanaman selada dengan sistem hidroponik dapat dilakukan pada lingkungan rumah tangga. Budidaya tanaman dengan sistem hidroponik merupakan model budidaya tanaman yang tidak menggunakan tanah sebagai media tanam. Sistem hidroponik dapat dibangun secara vertical sehingga memungkinkan untuk membudidayakan tanaman pada lahan yang terbatas (Sardare dan Admane, 2013).

Tanaman yang dibudidayakan dengan sistem hidroponik mendapatkan hara melalui pemberian larutan nutrisi. Larutan nutrisi yang digunakan untuk budidaya tanaman dengan sistem hidroponik dibagi menjadi dua, yakni larutan nutrisi organik dan larutan nutrisi anorganik. Pupuk organik cair (POC) bioslurry merupakan salah satu larutan nutrisi yang berbahan dasar dari bahan organik berupa hasil fermentasi limbah ternak yang telah digunakan sebagai bahan biogas dan bersifat mudah diserap oleh tanaman.(Simatupang dkk., 2016). AB mix merupakan larutan nutrisi anorganik yang diracik oleh manufaktur sehingga kandungan dan jumlah hara mikro dan makro yang terkandung di dalamnya mampu memenuhi kebutuhan tanaman yang dibudidayakan dengan sistem hidroponik (Nugraha dan Susila, 2016).

Pemberian larutan nutrisi pada tanaman yang dibudidayakan dengan sistem hidroponik baik dilakukan dengan tepat dosis. Pemberian dosis larutan nutrisi yang tepat dosis dan berimbang akan mendukung pertumbuhan tanaman yang baik (Adimihardja dkk., 2013). Larutan nutrisi yang digunakan untuk membudidayakan tanaman sebaiknya mengandung hara mikro dan makro yang lengkap. Tanaman yang kebutuhan hara makro dan mikronya tidak lengkap akan terkendala pertumbuhannya (Sarkar dkk., 2017). Tujuan dari penelitian ini adalah untuk mengkaji pengaruh pemberian larutan nutrisi bioslurry dan $\mathrm{AB}$ mix pada tanaman selada merah dan tanaman selada hijau yang dibudidayakan dengan sistem hidroponik apung.

\section{METODE PENELITIAN}

Penelitian ini telah dilakukan di Green House Blok C, dilanjutkan dengan analisis di Laboratorium Ekologi dan Produksi Tanaman, Fakultas Peternakan dan Pertanian, Universitas Diponegoro, Semarang. Penelitian ini dilakukan dengan menggunakan model rancangan Petak Terbagi (split plot) Rancangan Acak Lengkap (RAL). Petak utama terdiri dari lima taraf perlakuan dosis larutan nutrisi $(\mathrm{D} 1=70 \mathrm{~mL} \mathrm{AB}$ mix, $\mathrm{D} 2=52,5 \mathrm{~mL} \mathrm{AB}$ mix $+17,5 \mathrm{~mL}$ bioslurry, $\mathrm{D} 3=35 \mathrm{~mL} \mathrm{AB}$ mix $+35 \mathrm{~mL}$ bioslurry, $\mathrm{D} 4=$ $17,5 \mathrm{~mL} \mathrm{AB}$ mix $+52.5 \mathrm{~mL}$ bioslurry, D5 = 70 $\mathrm{mL}$ bioslurry). Anak petak terdiri dari dua jenis kultivar tanaman selada (K1 = selada merah, K2 = selada hijau). Satu unit percobaan diwakilkan oleh satu bak sistem hidroponik berisikan air sebanyak 7 L. Setiap unit percobaan dilakukan empat ulangan. Parameter yang diamati meluputi tinggi tanaman $(\mathrm{cm})$, jumlah daun (helai), kadar klorofil total $\left(\mathrm{mg} \cdot \mathrm{g}^{-1}\right)$, kadar aktivitas nitrat reduktase $\left(\mu \mathrm{mol} . \mathrm{g}^{-1} . \mathrm{jam}^{-1}\right)$, dan bobot segar tajuk (g). Data dianalisis dengan uji $\mathrm{F}$, dilanjutkan dengan uji lanjut beda nyata terkecil (BNT) dengan taraf $\alpha=5 \%$.

\section{HASIL DAN PEMBAHASAN}

\section{Tinggi Tanaman}

Berdasarkan penelitian yang telah dilaksanakan diperoleh data tinggi tanaman yang disajikan pada Tabel 1. Tanaman selada merah yang diberikan dosis larutan nutrisi $52,5 \mathrm{~mL} \mathrm{AB}$ mix $+17,5 \mathrm{~mL}$ bioslurry dan $35 \mathrm{~mL} \mathrm{AB} \mathrm{mix}+$ $35 \mathrm{~mL}$ bioslurry menghasilkan rata-rata tinggi tanaman yang lebih tinggi dibandingkan dengan pemberian dosis larutan nutrisi lainnya pada tanaman selada merah. Rata-rata tinggi tanaman yang tinggi menunjukkan pertumbuhan tanaman yang baik. Hal tersebut sesuai dengan pendapat Adimihardja dkk. (2013) yang menyatakan bahwa pemberian dosis larutan nutrisi yang memenuhi kebutuhan hara tanaman akan mendukung pertumbuhan yang baik pada tanaman yang dibudidayakan dengan sistem hidroponik. Tanaman selada merah yang diberikan dosis larutan nutrisi $70 \mathrm{~mL} \mathrm{AB} \mathrm{mix}$ menunjukkan rata-rata tinggi tanaman terendah 
sebesar 2,33 cm, dibandingkan dengan pemberian dosis larutan nutrisi lainnya pada tanaman selada merah. Rendahnya rata-rata tinggi tanaman disebabkan oleh pemberian dosis larutan nutrisi $\mathrm{AB}$ mix sebesar $70 \mathrm{~mL}$ menghasilkan tingkat electro conductivity (EC) pada larutan nutrisi yang terlalu tinggi untuk menumbuhkan tanaman selada merah, sehingga tanaman mengalami kejenuhan nutrisi. Hal tersebut didukung dengan pendapat Pratiwi dkk. (2015) yang menyatakan bahwa tanaman yang mengalami kejenuhan nutrisi akan kurang mampu menyerap nutrisi dengan baik, sehingga tanaman mengalami keracunan dan menyebabkan kematian tanaman

Tanaman selada hijau yang diberikan dosis larutan nutrisi $52,5 \mathrm{~mL} \mathrm{AB} \mathrm{mix}+17,5 \mathrm{~mL}$ bioslurry menghasilkan rata-rata tinggi tanaman tertinggi dibandingkan dengan pemberian dosis larutan nutrisi lainnya pada tanaman selada hijau. Rata-rata tinggi tanaman yang tinggi menunjukkan bahwa pemberian larutan nutrisi $52,5 \mathrm{~mL} \mathrm{AB}$ mix $+17,5 \mathrm{~mL}$ bioslurry mengandung hara nitrogen $(\mathrm{N})$ yang cukup untuk mendukung pertumbuhan tinggi tanaman yang optimal. Hal tersebut sesuai dengan pendapat Fariudin dkk. (2013) yang menyatakan bahwa tanaman yang diberikan larutan nutrisi yang mengandung hara $\mathrm{N}$ yang cukup akan menginduksi pembelahan sel pada tanaman, sehingga diperoleh pertumbuhan tinggi tanaman yang optimal. Tanaman selada hijau yang diberikan dosis larutan nutrisi $70 \mathrm{~mL}$ bioslurry menunjukkan rata-rata tinggi tanaman terendah dibandingkan dengan pemberian dosis larutan nutrisi lainnya pada tanaman selada hijau. Rendahnya rata-rata tinggi tanaman selada hijau yang diberikan dosis larutan nutrisi $70 \mathrm{~mL}$ bioslurry menunjukkan dosis yang diberikan kurang memenuhi kebutuhan hara tanaman. Hal tersebut didukung oleh pendapat Rohmaniyah dkk. (2015) yang menyatakan bahwa pemberian dosis larutan nutrisi yang kurang memenuhi kebutuhan hara tanaman akan menyebabkan tanaman menjadi kerdil.

Tabel 1. Rata-rata tinggi tanaman $(\mathrm{cm})$ selada pada berbagai dosis larutan nutrisi $\mathrm{AB}$ mix dan bioslurry yang berbeda.

\begin{tabular}{cccc}
\hline \multirow{2}{*}{ Dosis Larutan Nutrisi } & \multicolumn{2}{c}{ Kultivar Tanaman } & \multirow{2}{*}{ Rerata } \\
\cline { 2 - 3 } & Selada Merah (K1) & Selada Hijau (K2) & \\
\hline $70 \mathrm{~mL}$ AB Mix (D1) & $0,68^{\mathrm{d}}$ & $7,28^{\mathrm{c}}$ & 3,99 \\
$52,5 \mathrm{~mL}$ AB Mix $+17,5 \mathrm{~mL}$ Bioslurry (D2) & $8,78^{\mathrm{a}}$ & $14,43^{\mathrm{a}}$ & 11,63 \\
35 mL AB Mix + 35 mL Bioslurry (D3) & $7,26^{\mathrm{a}}$ & $10,21^{\mathrm{b}}$ & 8,75 \\
$17,5 \mathrm{mLAB}$ Mix + 52,5 mL Bioslurry (D4) & $5,45^{\mathrm{b}}$ & $5,75^{\mathrm{c}}$ & 5,61 \\
$70 \mathrm{~mL}$ Bioslurry (D5) & $2,33^{\mathrm{c}}$ & $2,74^{\mathrm{d}}$ & 2,55 \\
\hline Rerata & 4,92 & 8,08 & \\
\hline
\end{tabular}

Keterangan : Angka dengan superskrip yang berbeda pada kolom yang sama menunjukkan perbedaan nyata antar perlakuan pada uji BNT dengan taraf $5 \%$.

\section{Jumlah Daun}

Berdasarkan penelitian yang telah
dilaksanakan diperoleh data jumlah daun tanaman yang disajikan pada Tabel 2. Tanaman selada merah yang diberikan dosis larutan nutrisi $52,5 \mathrm{~mL}$ AB mix $+17,5 \mathrm{~mL}$ bioslurry menunjukkan rata-rata jumlah daun tertinggi dibandingkan dengan pemberian dosis larutan nutrisi lainnya pada tanaman selada merah. Tanaman selada merah yang diberikan dosis larutan nutrisi $52,5 \mathrm{~mL} \mathrm{AB} \mathrm{mix}+17,5 \mathrm{~mL}$ bioslurry memiliki rata-rata jumlah daun tertinggi dikarenakan kebutuhan tanaman akan hara $\mathrm{N}$ tercukupi. Pertumbuhan daun pada tanaman didukung oleh peran hara $\mathrm{N}$ di dalam tanaman. Hal tersebut sesuai dengan pendapat Wardhana dkk. (2016) yang menyatakan bahwa pemberian larutan nutrisi yang mengandung hara $\mathrm{N}$ secara tepat dosis akan meingkatkan pertumbuhan daun tanaman, sehingga tanaman akan memiliki jumlah daun yang lebih banyak. Tanaman selada merah yang diberikan dosis larutan nutrisi $70 \mathrm{~mL}$ $\mathrm{AB}$ mix menunjukkan rata-rata jumlah daun 
terendah dibandingkan dengan pemberian dosis larutan nutrisi lainnya pada tanaman selada merah. Rendahnya rata-rata jumlah daun menunjukkan bahwa pemberian dosis larutan nutrisi $70 \mathrm{~mL}$ AB mix yang diberikan pada tanaman selada merah sudah melebihi kebutuhan hara tanaman selada. Hal tersebut sesuai dengan pendapat Pratiwi dkk. (2015) yang menyatakan bahwa kebutuhan hara tanaman yang dipenuhi secara berlebih akan menyebabkan tanaman mengalami kejenuhan nutrisi dan mengganggu pertumbuhan daun tanaman.

Tanaman selada hijau yang diberikan dosis larutan nutrisi $52,5 \mathrm{~mL} \mathrm{AB} \mathrm{mix}+17,5 \mathrm{~mL}$ bioslurry menunjukkan rata-rata jumlah daun tertinggi dibandingkan dengan pemberian dosis larutan nutrisi lainnya pada tanaman selada hijau. Rata-rata jumlah daun yang tinggi menunjukkan bahwa pemberian dosis larutan nutrisi sudah sesuai karena mampu memenuhi kebutuhan hara tanaman. Hal tersebut sesuai dengan pendapat
Siregar dkk. (2015) yang menyatakan bahwa pemberian dosis larutan nutrisi yang sesuai akan mendukung peningkatan pertumbuhan daun tanaman. Tanaman selada hijau yang diberikan dosis larutan nutrisi $70 \mathrm{~mL}$ bioslurry menunjukkan rata-rata jumlah daun terendah dibandingkan dengan pemberian dosis larutan nutrisi lainnya pada tanaman selada hijau. Pemberian dosis larutan nutrisi $70 \mathrm{~mL}$ bioslurry secara individu tanpa campuran $\mathrm{AB}$ mix masih kurang mampu menmenuhi kebutuhan hara tanaman selada hijau dikarenakan kandungan hara pada bioslurry terlalu rendah untuk mendukung pertumbuhan tanman selada. Hal tersebut sesuai dengan pendapat Sentana (2010) yang menyatakan bahwa pemberian dosis larutan nutrisi organik seperti bioslurry mengandung hara dalam jumlah yang sedikit, sehingga sebaiknya diberikan dalam dosis yang lebih tinggi untuk diperoleh pertumbuhan tanaman yang baik.

Tabel 2. Rata-rata jumlah daun tanaman selada pada berbagai dosis larutan nutrisi AB mix dan bioslurry yang berbeda.

\begin{tabular}{cccc}
\hline \multirow{2}{*}{ Dosis Larutan Nutrisi } & \multicolumn{2}{c}{ Kultivar Tanaman } & \multirow{2}{*}{ Rerata } \\
\cline { 2 - 3 } & Selada Merah (K1) & Selada Hijau (K2) & \\
\hline $70 \mathrm{~mL}$ AB Mix (D1) & $0,88^{\mathrm{e}}$ & $5,06^{\mathrm{c}}$ & 2,97 \\
$52,5 \mathrm{~mL}$ AB Mix + 17,5 mL Bioslurry (D2) & $13,75^{\mathrm{a}}$ & $10,19^{\mathrm{a}}$ & 11,97 \\
35 mL AB Mix + 35 mL Bioslurry (D3) & $12,69^{\mathrm{b}}$ & $8,06^{\mathrm{b}}$ & 10,38 \\
$17,5 \mathrm{mLAB}$ Mix + 52,5 mL Bioslurry (D4) & $10,63^{\mathrm{c}}$ & $7,06^{\mathrm{b}}$ & 8,85 \\
$70 \mathrm{~mL}$ Bioslurry (D5) & $5,56^{\mathrm{d}}$ & $2,63^{\mathrm{d}}$ & 4,09 \\
\hline Rerata & 8,70 & 6,6 & \\
\hline
\end{tabular}

Keterangan : Angka dengan superskrip yang berbeda pada kolom yang sama menunjukkan perbedaan nyata antar perlakuan pada uji BNT dengan taraf $5 \%$.

\section{Kadar Klorofil Total}

Berdasarkan penelitian yang telah dilaksanakan diperoleh data kadar klorofil total tanaman yang disajikan pada Tabel 3. Pemberian larutan nutrisi $\mathrm{AB}$ mix dan bioslurry dengan dosis yang berbeda tidak menunjukkan perbedaan nyata terhadap rata-rata kadar klorofil total baik pada tanaman selada merah maupun pada tanaman selada hijau. Pemberian larutan nutrisi $\mathrm{AB}$ mix dan bioslurry dengan dosis yang memenuhi kebutuhan hara $\mathrm{N}$ tanaman selada merah dan selada hijau bertujuan untuk meningkatkan kadar klorofil total tanaman pada masing-masing kultivar tanaman. Hal tersebut sesuai dengan pendapat Wijiyanti dkk. (2019) yang menyatakan bahwa unsur hara $\mathrm{N}$ berperan penting pada saat tanaman berfotosintesis untuk menghasilkan protein dan klorofil, kebutuhan hara $\mathrm{N}$ yang terpenuhi akan meningkatkan kadar klorofil total pada tanaman. Rata-rata kadar klorofil total pada kedua kultivar tanaman selada yang tidak berbeda nyata dapat disebabkan oleh faktor genetis yang terdapat di dalam tanaman 
selada. Hal tersebut sesuai dengan pendapat Hasidah dkk. (2017) yang menyatakan bahwa setiap jenis tanaman memiliki kemampuan yang berbeda dalam menghasilkan pigmen klorofil, sehingga menyebabkan perbedaan jumlah klorofil total pada setiap jenis tanaman.

Faktor-faktor yang dapat mempengaruhi kadar klorofil total suatu tanaman dibagi menjadi faktor internal dan faktor eksternal. Faktor internal yang mampu mempengaruhi kadar klorofil total tanaman meliputi kadar hara $\mathrm{N}$ yang diserap oleh tanaman. Pemberian dosis larutan nutrisi yang mengandung hara $\mathrm{N}$ dapat dilakukan untuk meningkatkan kadar klorofil total yang terkandung di dalam tanaman. Nitrogen $(\mathrm{N})$ di dalam tanaman berperan dalam proses pembentukan pigmen klorofil (Wulandari dkk., 2017). Faktor eksternal yang mampu mempengaruhi kadar klorofil total tanaman meliputi intensitas cahaya yang diperoleh tanaman. Pengambilan sampel tanaman yang digunakan untuk uji klorofil sebaiknya dilakukan pada pagi hari yang cerah dimana inentsitas cahaya tinggi. Tanaman yang mendapatkan cahaya dengan intensitas yang tinggi akan memiliki kadar klorofil yang tinggi. Pengambilan sampel uji kadar klorofil total sebaiknya dilakukan pada pagi hari untuk memperoleh kadar klorofil total yang akurat (Yanti dan Ngadiani, 2018).

Tabel 3. Rata-rata kadar klorofil total (mg. $\left.\mathrm{g}^{-1}\right)$ tanaman selada pada berbagai dosis larutan nutrisi AB mix dan bioslurry yang berbeda.

\begin{tabular}{cccc}
\hline \multirow{2}{*}{ Dosis Larutan Nutrisi } & \multicolumn{2}{c}{ Kultivar Tanaman } & \multirow{2}{*}{ Rerata } \\
\cline { 2 - 3 } & Selada Merah (K1) & Selada Hijau (K2) & \\
\hline 70 mL AB Mix (D1) & 0,16 & 0,35 & 0,25 \\
52,5 mL AB Mix + 17,5 mL Bioslurry (D2) & 0,45 & 0,30 & 0,37 \\
35 mL AB Mix + 35 mL Bioslurry (D3) & 0,33 & 0,29 & 0,31 \\
17,5 mLAB Mix + 52,5 mL Bioslurry (D4) & 0,38 & 0,69 & 0,53 \\
70 mL Bioslurry (D5) & 0,17 & 0,42 & 0,30 \\
\hline Rerata & 0,30 & 0,41 &
\end{tabular}

Keterangan : Angka dengan superskrip yang berbeda pada kolom yang sama menunjukkan perbedaan nyata antar perlakuan pada uji BNT dengan taraf 5\%.

\section{Kadar Aktivitas Nitrat Reduktase (ANR)}

Berdasarkan penelitian yang telah dilaksanakan diperoleh data kadar ANR tanaman yang disajikan pada Tabel 4. Pemberian larutan nutrisi $\mathrm{AB}$ mix dan bioslurry dengan dosis yang berbeda tidak menunjukkan perbedaan nyata terhadap rata-rata kadar ANR baik pada tanaman selada merah maupun pada tanaman selada hijau. Kadar ANR pada kedua kultivar tanaman selada erat kaitannya dengan kadar klorofil total tanaman. Hal tersebut sesuai dengan pendapat Vishwakarma dkk. (2017) yang menyatakan bahwa tanaman dengan kadar klorofil total yang tinggi akan cenderung menunjukkan kadar ANR yang juga tinggi. Kadar ANR yang tinggi pada tanaman selada dapat dijadikan indikasi bahwa tanaman aman untuk dikonsumsi manusia. Hal tersebut didukung oleh pendapat Sifu (2017) yang menyatakan bahwa enzim ANR berperan dalam menurunkan kadar nitrat $\left(\mathrm{NO}_{3}^{-1}\right)$ yang bersifat berbahaya untuk dikonsumsi manusia dalam jumlah yang tinggi.

Jumlah kadar ANR suatu tanaman dipengaruhi oleh pemberian nutrisi pada tanaman. Rata-rata kadar ANR yang rendah dapat disebabkan oleh kurang terpenuhinya kebutuhan hara tanaman akan hara N. Hal tersebut sesuai dengan pendapat Latifa dan Anggarwulan (2009) yang menyatakan bahwa pemberian larutan nutrisi yang kaya akan hara $\mathrm{N}$ akan mampu meningkatkan kemampuan tanaman menghasilkan enzim ANR, sehingga rata-rata kadar ANR yang diperoleh akan meningkat. Biolsurry merupakan larutan nutrisi organik yang mengandung unsur hara yang bervariatif namun dalam jumlah yang sangat rendah. Rendahnya hara yang terkandung pada larutan nutrisi 
bioslurry masih kurang mampu untuk memenuhi kebutuhan hara tanaman selada merah dan selada hijau. Hal tersebut sesuai dengan pendapat Moncada dkk. (2018) yang menyatakan bahwa kebutuhan hara tanaman yang tidak terpenuhi akan mengganggu proses tanaman menghasilkan enzim ANR, sehingga kadar ANR yang dihasilkan rendah.

Tabel 4. Rata-rata kadar ANR $\left(\mu \mathrm{mol.g}^{-1} . \mathrm{jam}^{-1}\right)$ tanaman selada pada berbagai dosis larutan nutrisi AB mix dan bioslurry yang berbeda.

\begin{tabular}{cccc}
\hline \multirow{2}{*}{ Dosis Larutan Nutrisi } & \multicolumn{2}{c}{ Kultivar Tanaman } & \multirow{2}{*}{ Rerata } \\
\cline { 2 - 3 } & Selada Merah (K1) & Selada Hijau (K2) & \\
\hline $70 \mathrm{~mL}$ AB Mix (D1) & 1,04 & 3,34 & 2,19 \\
52,5 mL AB Mix + 17,5 mL Bioslurry (D2) & 2,35 & 2,15 & 2,25 \\
35 mL AB Mix + 35 mL Bioslurry (D3) & 1,99 & 2,69 & 2,34 \\
17,5 mLAB Mix + 52,5 mL Bioslurry (D4) & 3,06 & 2,93 & 2,99 \\
70 mL Bioslurry (D5) & 1,02 & 0,37 & 0,69 \\
\hline Rerata & 1,89 & 2,29 & \\
\hline
\end{tabular}

Keterangan : Angka dengan superskrip yang berbeda pada kolom yang sama menunjukkan perbedaan nyata pada antar perlakuan pada uji BNT dengan taraf 5\%

\section{Bobot Segar Tajuk}

Berdasarkan penelitian yang telah dilaksanakan diperoleh data bobot segar tajuk tanaman yang disajikan pada Tabel 5. Tanaman selada merah yang diberikan dosis larutan nutrisi $52,5 \mathrm{~mL} \mathrm{AB}$ mix $+17,5 \mathrm{~mL}$ bioslurry menunjukkan rata-rata bobot segar tajuk tertinggi dibandingkan dengan pemberian dosis larutan nutrisi lainnya pada tanaman selada merah. Tingginya rata-rata bobot segar tajuk pada tanaman selada merah yang diberikan dosis larutan nutrisi $52,5 \mathrm{~mL} \mathrm{AB} \mathrm{mix}+17,5 \mathrm{~mL}$ bioslurry didukung oleh rata-rata jumlah daun yang tinggi berdasarkan Tabel 2. Hal tersebut sesuai dengan pendapat Laksmono dan Sugiono (2017) yang menyatakan bahwa tanaman yang memiliki jumlah daun yang lebih banyak akan mampu melakukan fotosintesis dengan lebih baik, sehingga pertumbuhan tanaman meningkat dan hasil produksi tanaman berupa bobot segar tajuk lebih besar. Tanaman selada merah yang diberikan dosis larutan nutrisi $70 \mathrm{~mL} \mathrm{AB} \mathrm{mix} \mathrm{dan}$ $70 \mathrm{~mL}$ bioslurry menunjukkan rata-rata bobot segar tajuk yang lebih rendah dibandingkan dengan pemberian dosis larutan nutrisi lainnya pada tanaman selada merah. Rata-rata bobot segar tajuk yang rendah pada tanaman selada merah dikarenakan pemberian dosis larutan nutrisi $70 \mathrm{~mL}$ AB mix melebihi kebutuhan hara tanaman, sedangkan pemberian dosis $70 \mathrm{~mL}$ bioslurry kurang memenuhi kebutuhan hara tanaman. Hal tersebut didukung oleh pendapat Rohmaniyah dkk. (2015) yang menyatakan bahwa pemberian dosis larutan nutrisi yang tidak tepat dosis akan menyebabkan terganggunya pertumbuhan tanaman dan menghasilkan hasil produksi tanaman yang minim.

Tanaman selada hijau yang diberikan dosis larutan nutrisi $52,5 \mathrm{~mL} \mathrm{AB}$ mix $+17,5 \mathrm{~mL}$ bioslurry menunjukkan rata-rata bobot segar tajuk tertinggi dibandingkan dengan pemberian dosis larutan nutrisi lainnya pada tanaman selada hijau. Rata-rata bobot segar tajuk yang tinggi pada tanaman selada hijau yang diberikan dosis larutan nutrisi $52,5 \mathrm{~mL} \mathrm{AB} \mathrm{mix}+17,5 \mathrm{~mL}$ bioslurry dikarenakan kebutuhan tanaman akan hara $\mathrm{N}$ terpenuhi. Hal tersebut sesuai dengan pendapat Fariudin dkk. (2013) yang menyatakan bahwa kebutuhan hara $\mathrm{N}$ tanaman yang terpenuhi akan meningkatkan pertumbuhan tinggi tanaman dan daun, sehingga hasil produksi tanaman yang diperoleh ikut meningkat. Tanaman selada hijau yang diberikan dosis larutan nutrisi $70 \mathrm{~mL}$ bioslurry menunjukkan rata-rata bobot segar terendah dibandingkan dengan pemberian dosis 
larutan nutrisi lainnya pada tanaman selada hijau. Rendahnya rata-rata bobot kering pada tanaman selada hijau yang diberikan dosis larutan nutrisi $70 \mathrm{~mL}$ bioslurry disebabkan oleh kurang terpenuhinya kebutuhan hara tanaman. Hal tersebut didukung oleh pendapat Siregar dkk.
(2015) yang menyatakan bahwa kurang terpenuhinya kebutuhan hara tanaman akan menyebabkan pertumbuhan tanaman menjadi terganggu serta hasil produksi tanaman menjadi minim.

Tabel 5. Rata-rata bobot segar tajuk tanaman selada pada berbagai dosis larutan nutrisi AB mix dan bioslurry yang berbeda.

\begin{tabular}{|c|c|c|c|}
\hline \multirow{2}{*}{ Dosis Larutan Nutrisi } & \multicolumn{2}{|c|}{ Kultivar Tanaman } & \multirow{2}{*}{ Rerata } \\
\hline & Selada Merah (K1) & Selada Hijau (K2) & \\
\hline & \multicolumn{3}{|c|}{----------------------(g)---------------------' } \\
\hline $70 \mathrm{~mL}$ AB Mix (D1) & $1,09^{\mathrm{d}}$ & $4,50^{\mathrm{d}}$ & 2,80 \\
\hline $52,5 \mathrm{~mL}$ AB Mix $+17,5 \mathrm{~mL}$ Bioslurry (D2) & $79,16^{\mathrm{a}}$ & $50,69^{a}$ & 64,92 \\
\hline 35 mL AB Mix + 35 mL Bioslurry (D3) & $64,75^{\mathrm{b}}$ & $31,22^{\mathrm{b}}$ & 47,98 \\
\hline 17,5 mLAB Mix $+52,5 \mathrm{~mL}$ Bioslurry (D4) & $36,31^{\mathrm{c}}$ & $14,97^{\mathrm{c}}$ & 25,64 \\
\hline $70 \mathrm{~mL}$ Bioslurry (D5) & $0,38^{\mathrm{d}}$ & $0,08^{\mathrm{e}}$ & 0,23 \\
\hline Rerata & 36,34 & 20,29 & \\
\hline
\end{tabular}

Keterangan : Angka dengan superskrip yang berbeda pada kolom yang sama menunjukkan perbedaan nyata antar perlakuan pada uji BNT dengan taraf $5 \%$.

\section{KESIMPULAN}

Pemberian dosis larutan nutrisi $52,5 \mathrm{~mL} \mathrm{AB}$ mix $+17,5 \mathrm{~mL}$ bioslurry yang diberikan pada kedua kultivar tanaman selada yang dibudidayakan dengan sistem hidroponik apung menghasilkan rata-rata pertumbuhan dan hasil produksi tertinggi, dibandingkan dengan pemberian dosis larutan nutrisi lainnya pada masing-masing kultivar. Pemberian dosis larutan nutrisi $70 \mathrm{~mL}$ AB mix dan $70 \mathrm{~mL}$ bioslurry kurang sesuai untuk membudidayakan kedua kultivar tanaman selada dengan sistem hidroponik apung. Pemberian dosis larutan nutrisi AB mix dan bioslurry yang berbeda tidak berpengaruh nyata terhadap rata-rata kadar klorofil dan kadar ANR baik pada tanaman selada merah maupun pada tanaman selada hijau.

\section{DAFTAR PUSTAKA}

Adimihardja, S. A., G. Hamid, dan E. Rosa. 2013. Pengaruh pemberian kombinasi kompos sapi dan fertimix terhadap pertumbuhan dan produksi dua kultovar tanaman selada (Lactuca sativa L.) dalam sistem hidroponik rakit apung. J. Pertanian. 4(1):6-20.
Fariudin, R., E. Sulistiyaningsih, dan S. Waluyo. 2013. Pertumbuhan dan hasil dua kultivar selada (lactuca sativa 1.) dalam akuaponika pada kolam gurami dan kolam nila. J. Vegetalika. 2(1):66-81.

Hasidah , Mukarlina, dan D. W. Rousdy. 2017. Kandungan pigmen klorofil, karotenoid dan antosianin daun Caladium. J. Protobiont. 6(2):29-37.

Laksmono, R. A., dan D. Sugiono. 2017. Karakteristik agronomis tanaman kalian (Brassica oleraceae L. var. acephala DC) kultivar Full White 921 akibat jenis media tanam organik dan nilai ec (electrical conductivity) pada hidroponik sistem wick. J. Agrotek Indonesia. 2 (1):25-33.

Latifa, I. C., dan E. Anggarwulan. 2009. Kandungan nitrogen jaringan, aktivitas nitrat reduktase, dan biomassa tanaman kimpul (Xanthosoma sagittifolium) pada variasi naugnan dan pupuk nitrogen. J. Nusantara Bioscience. 1(2):65-71.

Moncada, A., A. Miceli, L. Sabatino, G. Iapichino, F. D'Anna, and F. Vetrano. 2018. effect of molybdenum rate on yield and quality of lettuce, escarole, and curly 
endive grown in a floating system. J. Agronomy. 8(171):1-16.

Nugraha, R. U., dan A. D. Susila. 2015. Sumber sebagai hara pengganti ab mix pada budidaya sayuran daun secara hidroponik. J. Hort. Indonesia. 6(1):11-19.

Pratiwi, O. R., M. Suhandi, dan E. Mustari. 2015. Pengaruh tingkat ec (electrical conductivity) terhadap pertumbuhan tanaman sawi (Brassica juncea L.) dengan sistem instalasi aeroponik vertikal. J. Agro. 2(1):50-55.

Rohmaniyah, L. K., D. Indradewa, dan E. T. S. Putra. 2015. Tanggapan tanaman kangkung (Ipomea reptans Poir.), bayam (Amaranthus tricolor L.), dan selada (Lactuca sativa L.) terhadap pengayaan kalsium secara hidroponik. J. Vegetalika. 4(2):63-78.

Sardare, M. D., and S. V. Admane. 2013. A review of Plant Without Soil - hydroponics. International J. of Research in Engineering and Technology. 2(3):299-304.

Sarkar, R. K., J. C. Jana, and S. Datta. 2017. Effect of boron and zinc application on growth, seed yield, and seed quality of water spinach (Ipomea reptans Poir.) under Terai Region of West Bengal. J. of Applied and Natural Science. 9(3):1696-1702.

Seifu, Y. W. 2017. Nitrate content in minimally processed lettuce (Lactuca sativa L.) as affected by fluorescent light exposure during storage. J. Plant Biochem. Phsyiol. $5(2): 1-5$.

Sentana, S. 2010. Pupuk organik, peluang dan kendalanya. Hal. D05-1-D05-4. Dalam Prosiding Seminar Nasional Teknik Kimia "Kejuangan". DIY Yogyakarta: 26 Januari 2010.

Simatupang, H., Hapsoh, dan H. Yetti. 2016. Pemberian limbah cair biogas pada tanaman sawi (Brassica juncea L.). JOM. Faperta. 3(2):1-11.

Siregar, J., S. Triyono, dan D. Suhandy. 2015. Pengujian beberapa nutrisi hidroponik pada selada (Lactuca sativa L.) dengan teknologi hidroponik sistem terapung (THST) termodifikasi. J. Teknik Pertanian Lampung. 4(1):65-72.

Supriyadi, U., D. Martino, dan E. Indraswari. 2017. Pengaruh taungan terhadap pertumbuhan selada merah (Lactuca sativa L. Var. Red Rapids) secara hidroponik wick. J. Pertanian. 1(1):1-8.

Vishwakarma, D., J. K. Thakur, and P. P. Singh. 2017. Effect of pgpr consortia on nitrate reductase and chlorophyll content of flag leaf of wheat. Int. J. of Chemical Studies. 5(6):672-674.

Wardhana, I., H. Hasbi, dan I. Wijaya. 2016. Respons pertumbuhan dan produksi tanaman selada (Lactuca sativa L.) pada pemberian dosis pupuk kandang kambing dan interval waktu aplikasi pupuk cair super bionic. J. Ilmu-ilmu Pertanian. 14(2):165-185.

Wijiyanti, P., E. D. Hastuti, dan S. Haryanti. 2019. Pengaruh masa inkubasi pupuk dari air cucian beras terhadap pertumbuhan tanaman sawi hijau (Brassica juncea L.). Buletin Anatomi dan Fisiologi. 4(1):21-28.

Wulandari, S., D. Harjoko, T. Djoko. 2017. Pertumbuhan selada dalam hidroponik substrat dengan perbedaan ukuran serat aren dan nutrisi. Hal. 165-172. Prosiding Seminar Nasional Fakultas Pertanian UNS. Solo: 30 Maret 2017.

Yanti, G. F. dan Ngadiani. 2018. Uji banding berbagai media tanam terhadap pertumbuhan selada merah (Lactuca sativa var. crispa L.) dengan media tanam hidroponik sistem NFT (Nutrient Film Technique). J. STIGMA. 11(1):23-32. 